\title{
The Choice of Materials in Early Tibetan Printed Books
}

\author{
Agnieszka Helman-Ważny
}

As Thomas Francis Carter (1882-1925) said in his book The Invention of Printing in China and Its Spread Westward, "Back of the invention of printing lies the use of paper" $(1955,3)$. Indeed this close relationship between paper and printing is true for printing developments in practically every geographical region where paper was used as a printing support. Both inventions, mutually dependent on each other, stimulated the development of book making technologies, which in turn had an impact on Tibetan cultural life and ultimately changed Tibetan society.

During the dynastic period Tibet experienced Buddhist influences from different directions; however, according to Tibetan historiography, it was eventually decided that all Buddhist literature would be inherited from what was available in India (Snellgrove and Richardson 1978, 70-71). At that time printing was in its infancy in China. In India, texts were written on palm leaves; printing technology was not yet considered. This is possibly one of the reasons why at that time (about 792) Tibetans had no immediate need for a new technology, and also why most Tibetan early prints originate from areas outside Tibet. Chinese sources usually locate the beginning of woodblock printing in Northwestern China and are keen to claim this invention, as are many others concerned with book cultures in Asia (Pan 2000, 265-266). The oldest surviving examples of printing in the Tibetan script are from Northwestern China. Archaeological finds from the ruins of the Tangut city of Khara Khoto, mostly dated from the 12th and 13th centuries, suggest that the idea of printing in the Tibetan language was inspired by the book culture of the Tangut kingdom (1038-1227).

The region where the greatest quantity of early block prints (xylographs) was found is the Turfan oasis in what is now Chinese Turkestan. Printed books are a small but significant part of the Turfan collection (see van Schaik in this volume). This location was first excavated by the expeditions of Grünwedel and von Le Coq in the years 1902 to 1907 (Carter 1955, 141). The early wood

(C) AGNIESZKA HELMAN-WAŻNY, 2016 | DOI 10.1163/9789004316256_025

This is an open access chapter distributed under the terms of the Creative Commons Attribution- 
prints discovered there are not only rubbings from stone inscriptions, but also stencils and pounces, printed textiles, seals of different sizes, and many examples of stamped figures of the Buddha (Carter 1955, 39). Of the printed books, the most popular is the concertina form printed in Uighur with black ink. These early block prints comprise the concertina form, the dpe cha or booklet format, and single sheets. The booklets contain ritual texts such as dhäranis, while the single printed sheets contain diagrams printed for ritual purposes. These block prints were probably produced mainly in Chinese workshops, despite the fact that they were found in many places in the Turfan oasis, and they contain Chinese, Tangut, Mongolian, Tibetan, Old Turkish, and Sanskrit texts, most of which can be dated to the 13th and 14th centuries, with only singular examples dated to the 9 th. ${ }^{1}$ It should also be mentioned that many of these sūtra translations - regardless of language - exhibit Chinese pagination (Carter 1955). Interestingly, Chinese pagination (in Chinese characters) can be found in many of the early woodblocks in Tibetan produced outside Tibet proper.

Leonard van der Kuijp points to 13th-century evidence for the preparation of a xylograph with the Tibetan text of the Tshad ma rigs pa'i gter and the autocommentary of Sa skya Pandita Kun dga' rgyal mtshan (1182-1251) preserved in the Tibetan Library of the Cultural Palace of Nationalities in Beijing (van der Kuijp 1993, 279-298). The printing of Tibetan Buddhist texts increased during the period of Mongol rule over Tibet and China (1271-1368), often sponsored by queens at the Mongol court, and printed in Beijing (see Sherab Sangpo in this volume). This explains why there is more evidence concerning the various Mongol-sponsored printing projects propagating the Kālacakra literature first in China and then in Mongolia dated to the last decade of 13th century or the first decade of the 14th century. These prints are generally known under the name 'Mongol xylographs' (hor par ma; Ehrhard 2000, 11). The only early datable Tibetan work currently known was printed in China under Mongol patronage no later than the 1270 (Schaeffer 2009, 9). Schaeffer mentions the very significant role of 'Phags pa bLo gros rgyal mtshan $\left(1235^{-1280}\right)$ in the dissemination of printing technology in Tibet. In his printing projects, Tibetan and Chinese craftsmen worked together sponsored by Mongol leaders Yesu Boga and Hayimdu (Schaeffer 2009, 10). There is also an example of a volume of The Kālachakra Tantra (Tantraraja Shrikalachakratantra or Laghukalacakratantra; dus 'khor rgyud) printed from woodblocks and carved for the funeral ceremonies of the Kublai Khan (1215-1294) sponsored by Khublai Khan's wife and son that supports the above-mentioned dates. This book is in pothi format, with six

1 Berlin-Brandenburg Academy of Sciences and Humanities. Turfan Studies. Berlin 2007. 
lines of text printed between two side margins executed with a single line and Chinese pagination on the right side and Tibetan on the left of the recto of the folio. It displays a high-quality printing production with regular and proportional letters aligned to the top line of text. The lower parts of the head of the letters were cut with a rounded chisel. This feature of the letters' execution is shared with the first editions of Tibetan Kanjur produced in Beijing (especially Yongle and Wanli; Helman-Ważny 2014, 123, 153).

The best known works of Tibetan printing culture are the editions of the Tibetan Buddhist Canon. This collection of Buddhist scriptures underwent a final compilation in the 14th century by bCom ldan Rig pa'i ral gri (1227-1305) and Bu ston Rin chen grub (1290-1364). The Tibetans did not have a formally arranged Mahāyāna canon and so devised their own scheme, which divided texts into two broad categories: Kanjur and Tanjur. In general, the combined number of volumes of the two parts is over 300 , and each side of a single page is printed from an individually carved woodblock (Harrison 1996, 81).

It is still believed by many scholars that before 1410 , when the first woodblock edition of the Tibetan Kanjur was produced in Beijing, all Buddhist canonical collections were produced and reproduced as handwritten manuscripts. The Translation of the Word (Kanjur) and The Translation of Treatises (Tanjur) undertaken in 1410 by the Yongle Emperor (r. 1402-1424), is known as the first large-scale printed edition and almost nothing prior is known with certainty. In Beijing, new impressions continued to be taken from the Yongle blocks and in this way, the Wanli edition printed in black ink in 1606 was produced under the sponsorship of the Wanli emperor $\left(1563^{-1620}\right)$. When the blocks wore out, new blocks were prepared and carved using prints taken from the old blocks as a master. These are represented by the Qing dynasty re-edition and its reprints. Since the 17th century, Kanjur sets have been created, edited, and produced in Tibet and Mongolia.

The earliest surviving printed book from Central Tibet (Tibet proper) is dated to 1407 , a commentary on the Abhisamayālaṃkära by Haribhadra, printed to commemorate the death of Situ Chos kyi rin chen (1402) under the auspices of the scholar Bo dong Phyogs las rnam rgyal (1376-1451). The colophon celebrates Situ Chos kyi rin chen in relation to the Yuan emperors, suggesting that this early printing activity in Central Tibet was conceived on the model of Kublai Khan's sponsorship of the printing of Tibetan Buddhist texts (Diemberger forthcoming).

In the 1420 s and 30 s the collected works of Tsong kha pa (1357-1419) were printed with the sponsorship of the ruling house of Phag mo gru pa. The production of printed books increased through the 15th century, with 
the establishment of many small printing houses (par khang) in Central Tibet (Ehrhard 2000).

By the time printing appeared in Tibet, the technology of papermaking had already been known there. The art of papermaking eventually reached Tibet from China, most probably around $65^{\circ} \mathrm{CE}$. Tibetan and Chinese historiography links it traditionally to the arrival of the Chinese wife of Emperor Srong btsan sgam po. While there is a suggestion that paper was already available in the pre-existing Shangshung kingdom and that the invitation letters to the Chinese imperial princess were already written on paper (Tsundru 2010), this claim has so far been supported only by relatively late sources. The earliest preserved manuscripts on Tibetan paper made of Daphne fibres discovered in Mogao grottoes near Dunhuang are dated to the 9th century (and were presumably produced in Central Tibet; Helman-Ważny and van Schaik 2013). Characteristics of the paper in these manuscripts clearly suggest that Tibetans established their own papermaking tradition and created a unique type of paper by using an individual 'floating' mould, which is placed on a water surface such as lake, pond, river, or puddle. Paper pulp is prepared by beating the materials upon a stone with a wooden mallet; this pulp is then mixed with water and poured on the mould in measured quantities. The papermaker moves the frame in the water until the pulp entirely and equally covers the surface of the mould; he then tilts the frame until the water drains off. The papermaking mould with its newly made sheet of paper is then left undisturbed until the sheet is dry. ${ }^{2}$

The specificity of Tibetan papermaking lies in the properties of the native plants used, the living conditions of peoples dwelling on the world's highest

2 The other main type of paper mould is usually known as a 'dipping' mould, and is thought to have developed subsequent to the floating mould. The dipping mould allows faster paper production because it is possible to remove a wet sheet of paper directly from the sieve just after its shaping. This means that papermakers do not need to wait until the paper has dried before re-using the mould to begin the next sheet. The main difference between the two types of mould is in their construction. The floating mould is built of a wooden frame with a woven textile attached to it. In the dipping mould, on the other hand, a movable sieve made from bamboo, reed or another kind of grass is attached to the wooden frame. Independently of the techniques of the sheet formation, any papermaking sieve makes an impression that is specific to the construction of the mould and sieve. This print is unaffected by most aging processes, and can be read centuries later. The print of a textile sieve made of cotton, hemp, or flax differs clearly from that of a movable sieve from a dipping mould made of bamboo, reed or other grasses. However, it is possible that a floating mould could have been used together with bamboo sieve placed inside. 
plateau, and aspects of Tibetan culture that, together, created a distinctive craft. The high altitude of the Tibetan Plateau and the extremes of its climate make the vegetation distinctive from all other areas of Asia. Original Tibetan paper was made mainly from the phloem of shrubs belonging to the Daphne and Edgeworthia species (shog shing in Tibetan) at least by the 9th century (as suggested by the earliest preserved Tibetan manuscript from Dunhuang mentioned above), and the roots of the Stellera chamaejasme species (re lcag $p a$ in Tibetan) at least by the 1oth century in Central Tibet. The usage of plants with poisonous properties which were possibly chosen for this specific quality in the paper makes it resistant to damage caused by insects, and, ultimately, it is longer lasting than other types of paper.

The visual appearance of paper is affected by the type of raw material used, the technological process of paper production and its tools, and finally from the preparation of leaves of paper during book production. The choice to use certain plant fibres, which comprise the basic component of any paper sheet, has strongly shaped the aesthetics of a given culture's paper. Also, the printer or scribe chooses materials to match their skills and creative impetus. But beyond the raw materials, there are other aspects of the papermaking process which influence the nature of the resultant paper, such as the degree of fibre blending, the type of papermaking mould used, and the preparation of the paper surface before writing or printing. Also, different types of paper are required for manuscripts and printed books, as different qualities of paper are favourable by different way of text execution and its tools and methods.

The text is usually printed from wooden blocks by hand on paper that is relatively soft in comparison to paper used for manuscripts. These tend to have highly processed and sized surfaces to allow ink to be spread by pointed tool. Thus the main feature which should be adjusted differently for manuscripts and prints is paper absorbency. ${ }^{3}$ Furthermore, the quality of any printing has always depended on the type of paper support, the quality of the inks and wooden blocks used, and the skill of the craftsmen. A very fine quality print usually comes from the perfect match of ink thickness (viscosity) and type of paper. ${ }^{4}$ This conscious selection of materials provides a refined appearance that is the result of sharp, fine lines with little blurring. This refinement is also reflected in the appearance of the verso side of the leaf; when ink does not

3 Absorbency is the ability of a material to take in other substances with which it is in contact, either in liquid or gaseous form; the process of absorption is associated with changes in its physical or chemical properties (Banik and Brückle 2011, 492).

4 The viscosity of a fluid is a measure of its resistance to gradual deformation by shear stress or tensile stress. For liquids, it corresponds to the informal notion of "thickness". 
bleed through, the paper was accurately sized. Thus we can say that the final result of printing is dependent upon the interaction of many components. Sometimes the discovery of a new tool or method revolutionized earlier printing practices. For instance, printing in larger formats required increasing the thickness of the paper by gluing sheets together in layers. This step was necessary because thinner paper would not provide the stability necessary for a large format. In this way we can see how the overall function of the book influenced the selection of paper used in its creation.

All this explains the variety of paper types, which is confirmed by this study, found in Tibetan printed books.

\section{$2 \quad$ Results and Discussion}

\subsection{Paper in Early Prints Excavated along the Silk Road}

The earliest known datable printed work in Tibetan language (but not from Tibet proper) is a small prayer produced in Khara Khoto, a Tangut city in western Inner Mongolia, in 1153 and preserved in the Institute of Oriental Manuscripts in St. Petersburg. ${ }^{5}$ This is a double-sided, printed, 23 -folio booklet $(17.3 \times 12.7 \times 0.6 \mathrm{~cm})$ composed of 12 bi-folios folded in half. Every bi-folio includes six lines of text printed on each page in a full frame $15.8 \times 9.6 \mathrm{~cm}$ separated by the folding mark in the middle. It is printed with black ink on laid patchy paper glued in two layers characterized by 21 to 22 laid lines in $3 \mathrm{~cm} .{ }^{6}$ I identified the paper as rag paper composed of hemp. (Fig. 23.1) The texture of the paper is soft and absorbent, with brush traces originating from gluing the layers together.

Interestingly, other examples of early printed works are made on different types of paper. A famous example in Chinese language is the 'Diamond Sutra'. Printed in 868, the Diamond Sutra is the world's earliest dated complete

5 Accession number: Kh-Tib.67. For discussion of printing technology see Shi Jinbo 2005; Stoddard 2010.

6 Laid lines are horizontal line patterns visible when looking at the paper against light, which reflect the type of papermaking sieve used during papermaking process. A textile sieve differs clearly from that made of bamboo (laid regular), reed, or other grasses (laid irregular), and when sealed in the paper structure, this allows us to distinguish handmade woven paper and handmade laid paper characterized by the particular number of laid lines in $3 \mathrm{~cm}$. These can be categorized as: laid, regular where unequivocal clear evidence; laid, irregular where the pattern is not regular; and, finally, laid, patchy where the pattern can only be seen in patches of the paper but could not have been made by anything else. 


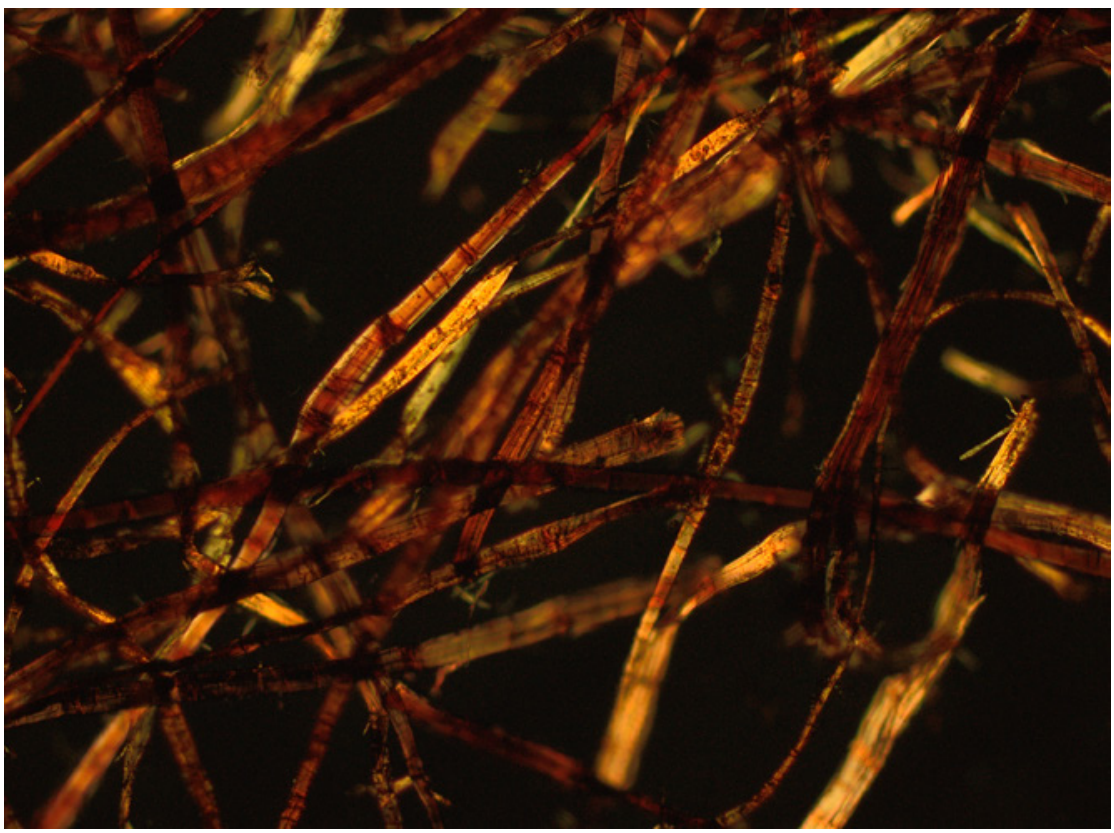

FIGURE 23.1 Hemp (Cannabis sativa) fibres stained reddish with Herzberg in $100 \times$ magnification. The rag paper composing a small prayer printed in Khara Khoto, the earliest printed work in Tibetan language currently known, datable by colophon to 1153. The print belongs to the collection of the Institute for Oriental Manuscripts in St Petersburg, Kh-Tib. 67.

printed book.7 It is a scroll, a continuous length of wood-block printed text made of seven panels of good quality paper pasted together to extend over $5 \mathrm{~m}$. The Diamond Sutra's paper is composed of Broussonetia sp. (Paper mulberry) fibres ${ }^{8}$ (Fig. 23.2). Fibre distribution in the paper clearly suggests that it is mostly of a woven type made using the 'floating' mould with textile sieve

7 My research on Chinese manuscripts from Dunhuang was funded by the Deutsche Forschungs-Gemeinschaft (DFG) within the project (2010-2013) "History and typology of paper in Central Asia during the first millennium AD: Analysis of Chinese paper manuscripts," Abteilung für Sprache und Kultur Chinas, Universitat Hamburg/AAI, Germany (Grant number Fr702/9-1). The author would like to acknowledge the help and support of the director of the International Dunhuang Project (IDP) Susan Whitfield, British Library.

8 The accidental addition of woven fabric was detected by Shoji Sakamoto only on Panel 2 of the Diamond Sutra scroll. Rag fibres however were not present as components of paper in rest of panels of the scroll. See the photograph taken with 16-bit digital microscope of panel 2 $\times 100$ magnification by Shoji Sakamoto in the International Dunhuang Project database: http://idp.bl.uk/database/large.a4d?recnum=18824\&imageRecnum=340461. 


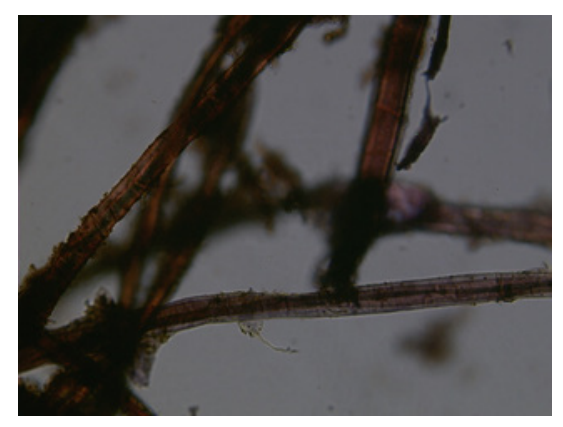

FIGURE 23.2

Paper mulberry (Broussonetia sp.) fibres composing the Diamond Sutra's paper stained reddish-brown with Herzberg in 6oo ×magnification. Fibres visible on the picture are characterized by a transparent membrane indicating a primary wall enveloping the fibre. The book is from British Library Collection.

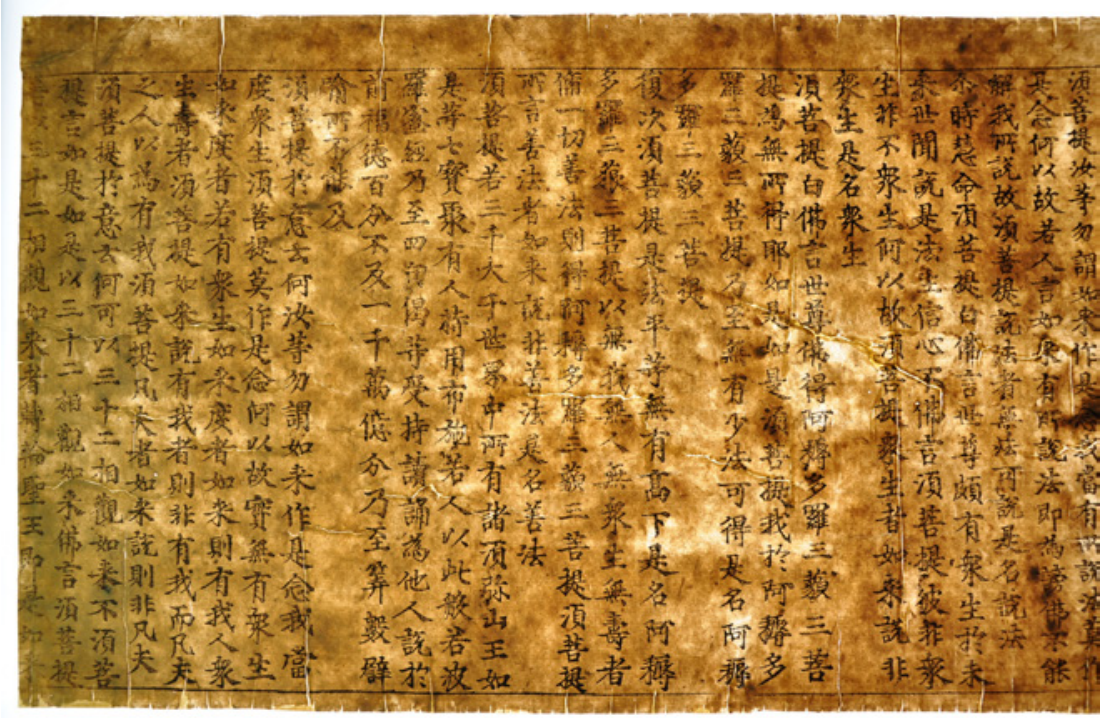

FIGURE 23.3 The paper of the Diamond Sutra's panel 6 viewed against the light. The faint laid lines suggesting the usage of a bamboo sieve attached to the 'floating' mould with a textile sieve visible in this picture. The book is from the British Library Collection.

(Fig. 23.3). However, we can also observe very faint laid lines in the paper of panel 6, which suggest that the paper for this panel was made using a bamboo sieve attached to the 'floating' mould. The best quality print in the whole Sutra is represented by the frontispiece on panel 1 . The direction of fibres distributed within panel 1 shows a clock-wise, patchy circle shape visible in the middle, and this is typical for woven paper when the papermaker pours the pulp on the floating sieve and stirs it (clock-wise) to distribute around the sieve. Here in the paper we have a witness of this stirring, both in the circular pattern and from 
its uneven thickness (0.14-0.22 $\mathrm{mm}$ measured at 10 different points within the paper sheet). Additionally, an evenly increased thickness along one edge suggests that this sheet was left to dry on the mould standing vertically, the wet pulp sinking slightly with gravity.

A block print from Turfan in Uighur language (U 4753) executed in six vertical text lines per page on a single-layered woven type of paper (size $10.5 \times 14 \mathrm{~cm}$ ) is composed of a blend of bamboo, paper mulberry and straw fibres. ${ }^{9}$ Despite its different components, the paper is soft and absorbent. The variety and type of components present in this sample suggest a rather later origin, since the mixing of bamboo, paper mulberry, and straw fibres was not seen before the 12th century. This combination is typical for later editions of Tibetan Canonical works produced in Beijing.

\subsection{Early Printed Tibetan Kanjurs}

Tibetan papers in the early printed Kanjur volumes do not represent a large variety. I could distinguish two main types of paper used in the examined sets of Yongle and Wanli Tibetan Kanjur. The main differences between the two types are found in fibre composition and traces of the type of papermaking sieve sealed in the paper structure. ${ }^{10}$ Early Yongle and Wanli Kanjur sets produced in China used paper made of pure paper mulberry fibres, while later volumes such as the Wanli Supplement were printed on paper with mixed fibre components. ${ }^{11}$ Regarding regional origin, all Kanjur sets produced in the Beijing area were executed on paper made of typically Chinese components such as pure paper mulberry or mixed with bamboo or straw fibres. These papers were characterized by about $24-30$ laid lines in 3 centimetres, and were produced using a mould with bamboo or grass sieve.

\subsection{The Earliest Extant Prints from Central Tibet}

The earliest surviving printed book from Shel dkar, Central Tibet, is dated to 1407, a commentary on the Abhisamayālaṃkāra by Haribhadra, printed to

9 Collection of the Berlin Brandenburg Academy of Sciences and Humanities (ввAW) and the Berlin State Library, Orientabteilung, U 4753.

10 In Tibet, primarily Thymelaeaceae family plants were used for producing paper. This makes Tibetan paper very distinctive from Chinese, which is composed of a variety of plants such as paper mulberry, bamboo, and straw among many others. For further information on Tibetan and Chinese papermaking, see Hunter 1932 and 1978; Meisezahl 1958, 17-28; Trier 1972, Tsien 1973, 510-519; Tsien 1985; McClure 1986; Koretsky 1986; Pan 1998; Helman-Ważny 2005 and 2006, 27-37 and 3-9.

11 For a detailed study of paper in 6o volumes of the Tibetan Wanli Kanjur see: Mejor et al. 2010, 32-51. 
commemorate the death of Situ Chos kyi rin chen (1402) under the auspices of the scholar Bo dong Phyogs las rnam rgyal (1376-1451). ${ }^{12}$ This text was discovered by the Paltseg Research Institute in collaboration with the University of Cambridge and the British Library (Diemberger 2012; Diemberger and Clemente 2014). Thus, this book is the earliest print in Tibetan language with confirmed origin from Tibet proper. The paper on which this book is printed is composed of two types of fibres: narrow with broad portions stained olivegrey identified as Daphne/Edgeworthia sp.; and ribbon-like with a very wide and irregular lumen identified as Stellera chameajasme. The good condition of these preserved fibres suggests paper of a good quality. The majority of the fibres is Daphne/Edgeworthia sp., showing clearly that Stellera was an addition. Besides these, I also observed an orange fibre in the pulp - very long, brightly stained (with Herzberg) dark yellow/orange fragments of parenchyma cells that lacked crystals on the fibre surface (Fig. 23.4).

I studied two other printed books from the same region dated later, to 1422 and 1539. The paper in the earlier print shares the same fibre composition as the above 1407 print: Daphne/Edgeworthia sp. fibres with addition of Stellera sp. fibres. Singular, (stained) yellow sclereids (short with thick walls) are also present in the pulp (Fig. 23.5). However, the condition of fibres in this pulp suggests slightly worse quality of fibres than in the 1407 print.

The 1539 print is different from the two earlier samples. The fibre content shows very good quality, uniform, and long fibres, more flabby (slender) and more ribbon-like in shape, narrow with an irregular lumen and broad portions typical of plants in the Thymeleaceae family, possibly Edgeworthia sp. (Fig. 23.6). A substantial amount of glue is visible on the fibre surface, which may suggest some paper processing.

Further studied were 18 samples taken from three different sources, as follows: 10 printed volumes classified as early Gung thang prints from the Tucci Collection at the Instituto per l'Africa e l'Oriente (IsIAO); ${ }^{13}$ three samples from Mani bka' 'bum volumes from Gung thang preserved in the Kathmandu National Archives in Nepal; and five samples from the British Library Collection in London. The results are significantly unified. All the papers I studied are composed of either pure Edgeworthia/Daphne sp. fibres or Edgeworthia/ Daphne sp. fibres mixed with various amounts of Stellera chameajasme (Fig. 23.7 and 23.8). The samples mostly differ in the amounts of Stellera or

\footnotetext{
12 See Porong Dawa in this volume and Diemberger forthcoming.

13 Studied printed books were selected by Dr. Michela Clemente from IsIAO Collection, as follows: v. 286/3 f. 7, v. 706 f. 1, v. 363/2 f. 343a, v. $697 / 6$ f. 1, v. 706 f. 1, v. 707 f. 1, v. 987 f. 118, v. 1466 f. 2 , v. $657 / 5$ f. 1, v. 671 f. 4, v. 771 f. 2 .
} 


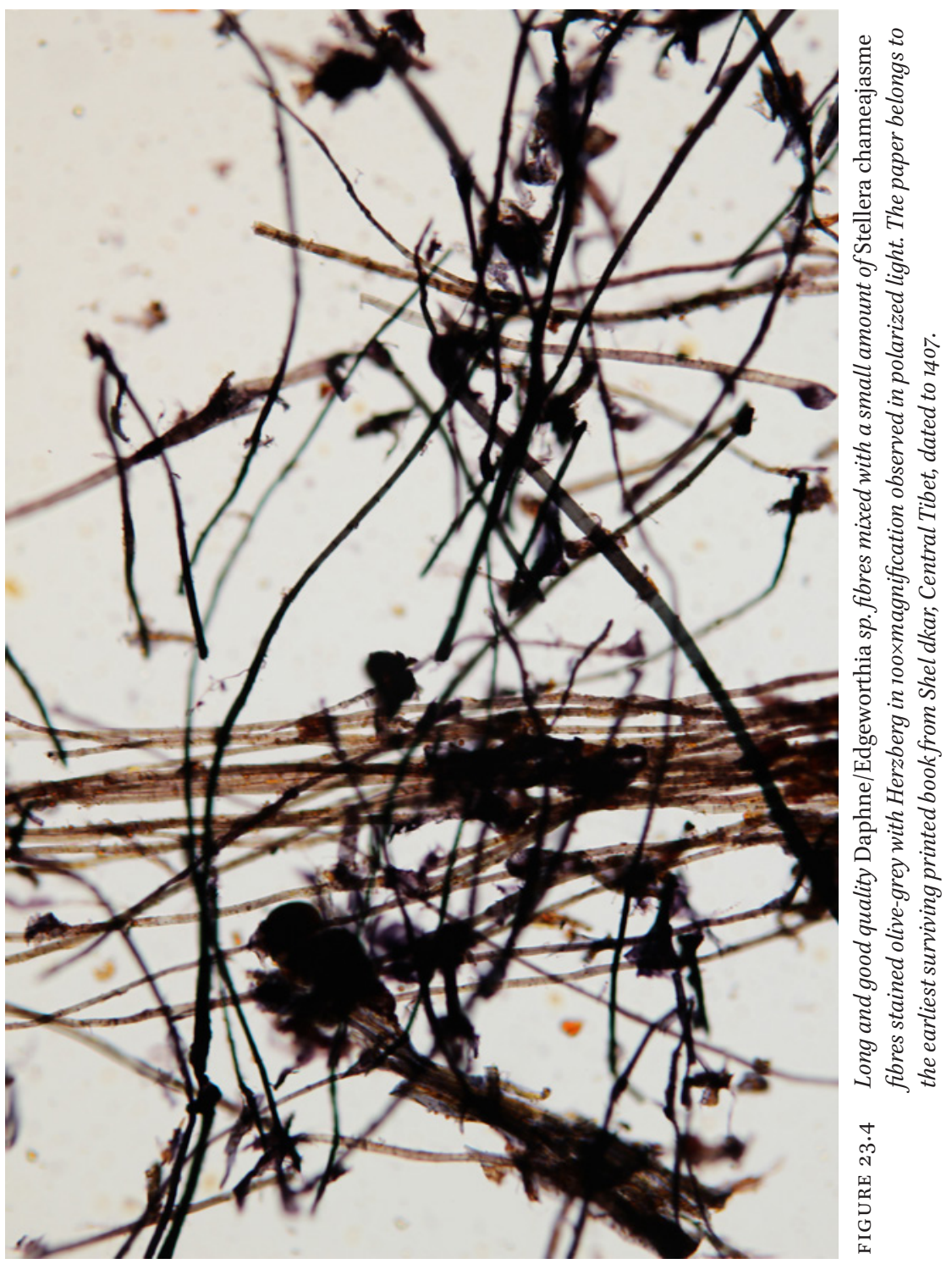




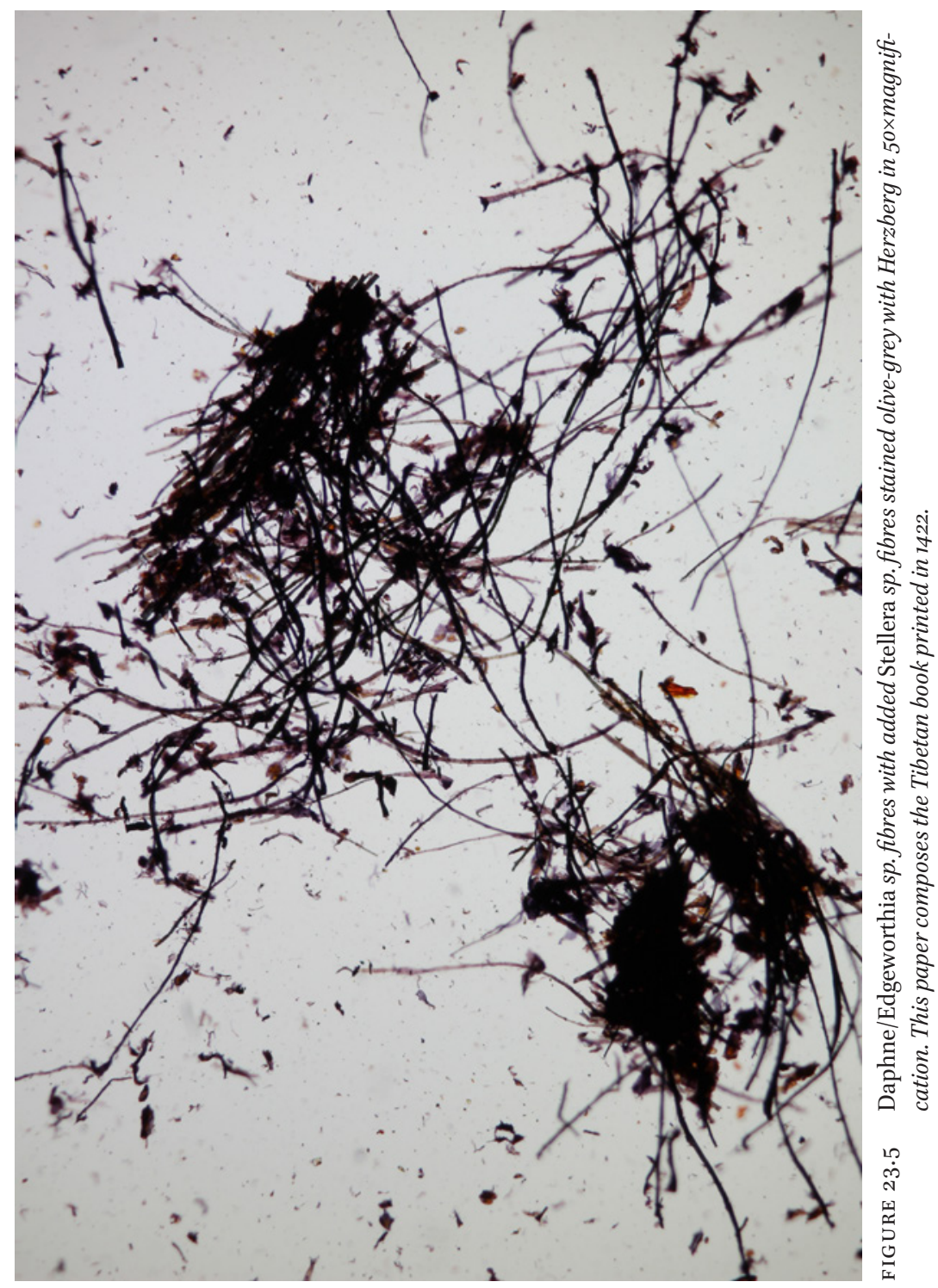




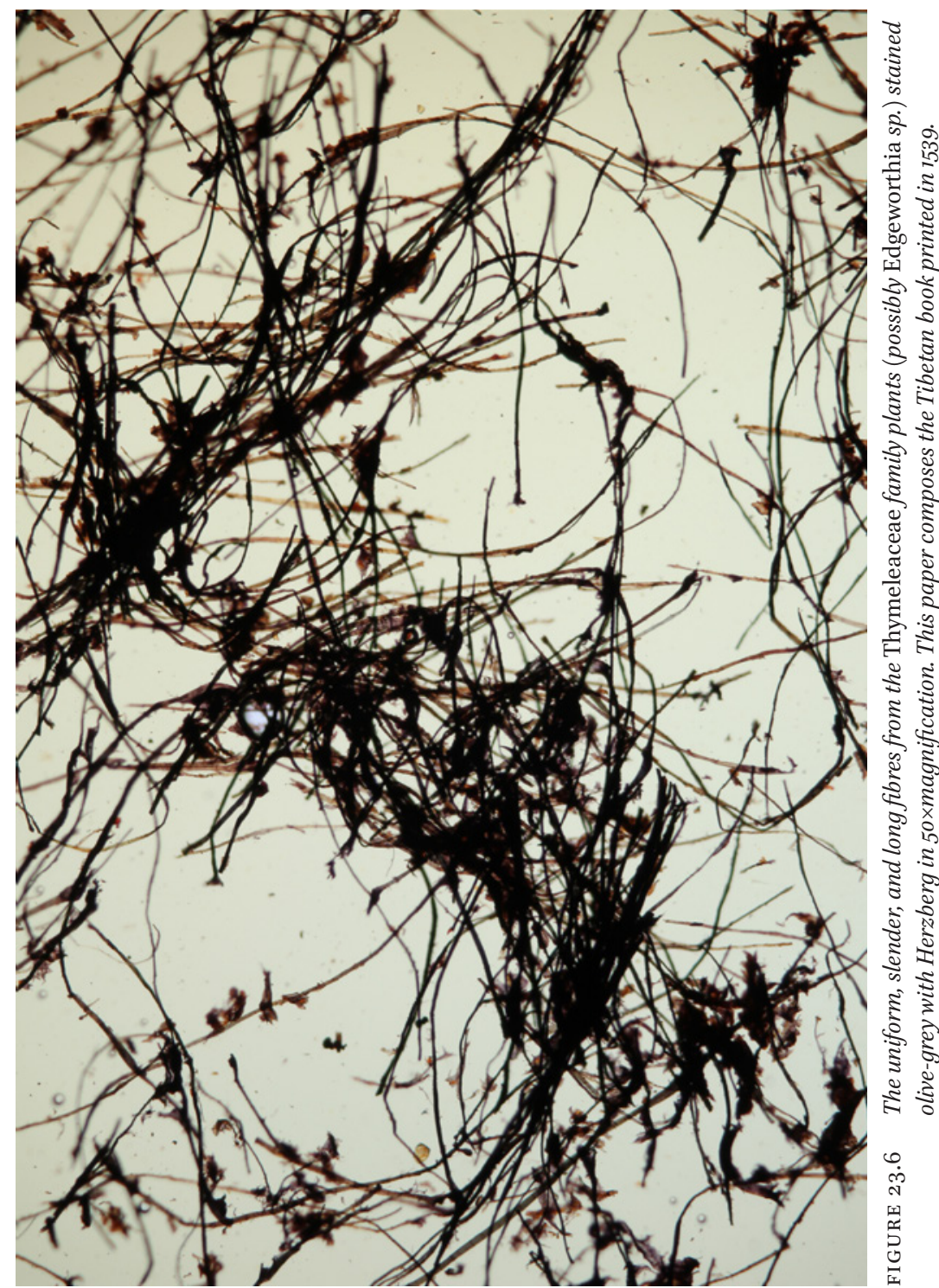




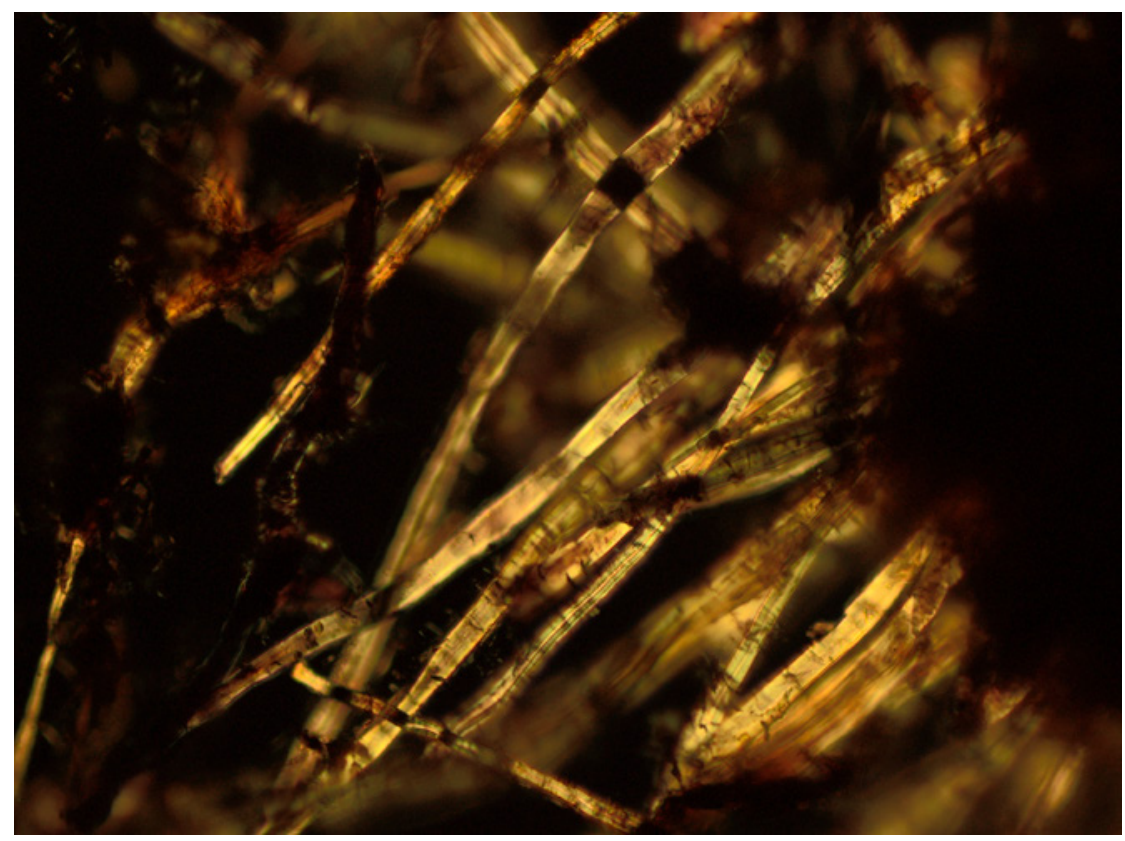

FIGURE 23.7 Daphne/Edgeworthia sp. fibres mixed with a small amount of Stellera chameajasme fibres stained olive-grey with Herzberg in $200 \times$ magnification observed in polarized light. Notice the varying fibre width and irregularities in fibre wall thickness, the many flattened places and dislocations. The lumen often narrows or wholly disappears. The paper sample belongs to the Tibetan book printed in early 16 th $c$. in Gung thang region. The book belongs to the Tucci Collection at the Instituto per l'Africa e l'Oriente (IIIAO), v. 286/3f.7.

other cells present in the pulp, such as parenchyma cells and fragments of parenchyma tissue, sclereids, the condition of fibres and stage of fibre lignification. These minor variations result in slight differences in the general quality of the papers, but in fact we can classify this entire group of papers as one unified type preferred by craftsmen for early prints in Central Tibet. Very few samples were composed of purely Daphne/Edgeworthia sp. fibres - only those taken from the Gung thang Mani bka' 'bum volumes dated to early 16th c. from Kathmandu National Archives. Interestingly, there was no instance of a book printed on pure Stellera paper detected among the samples studied (Fig. 23.9). We can observe a similar pattern from the fibre analysis of printed book samples from the British Library Collection. ${ }^{14}$

14 OR 16756msf3, Tib I 156 f 169, Tib 19999 A3, Tib 19999 dio7 fi24, Tib 19999 d41, Tib Mss I 18 PTI f. 


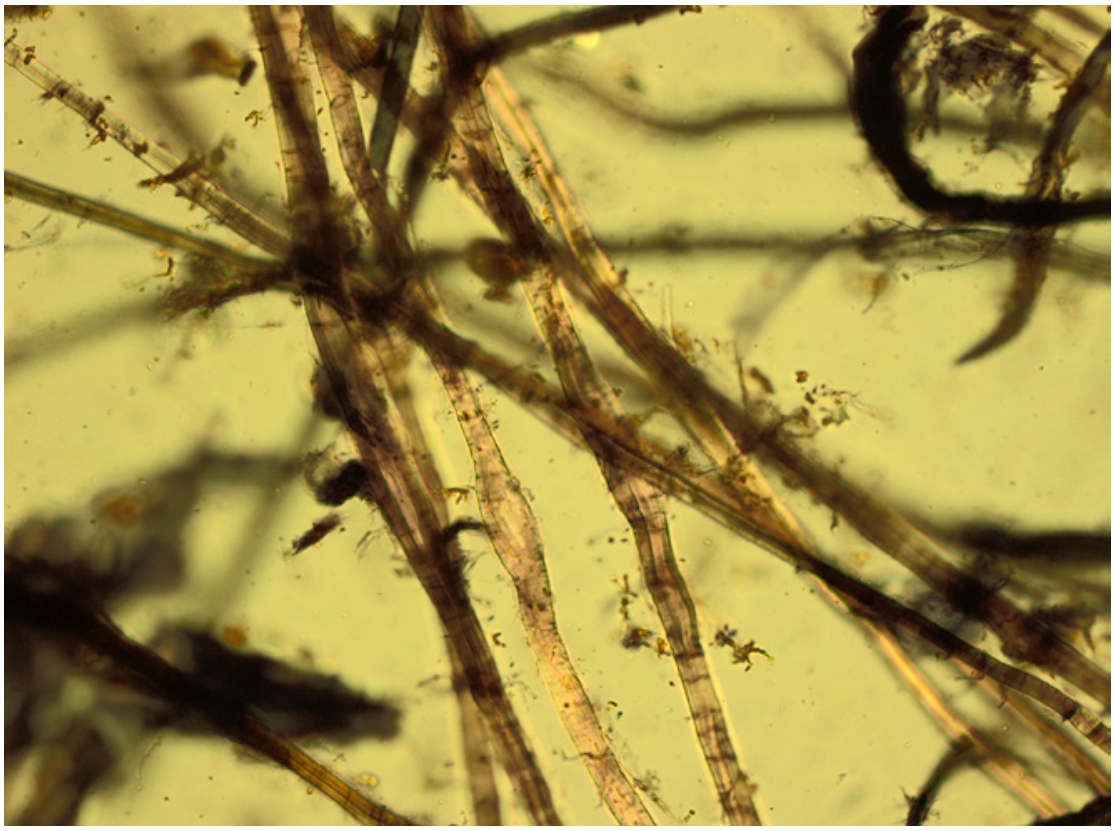

FIGURE 23.8 Daphne/Edgeworthia sp. fibre mixed with Stellera chameajasme fibres olive-grey/greenish with slightly pink coloured lumen with Herzberg in $200 \times$ magnification observed in polarized light. Notice the comparatively great fibre thickness in broad portions, the varying wall thickness, the many flattened places and dislocations. The paper sample belongs to the Tibetan book printed in early 16 th c. in Gung thang region. The book belongs to the Tucci Collection at the Instituto per l'Africa e l'Oriente (IsIAO), v. 706 f.r.

\subsection{The Tibetan Manuscripts from Central Tibet}

As a reference for comparison with the paper used in printed books, I examined paper in the Phu ri Collection of manuscripts discovered by Sherab Sangpo in the homonymous location ${ }^{15}$ and now preserved in Tibet University Library. Of the 10 samples from these manuscripts dated as early as the gth century one was written on pure Daphne/Edgeworthia sp. paper; four on Daphne/ Edgeworthia sp. mixed with Stellera sp.; three on paper made of Stellera sp. with only a slight addition of Daphne/Edgeworthia sp. or unidentified fibres;

15 Phu ri is currently located in the northern part of gNya' lam County in the western part of southern Lato (La stod lHo). This area was particularly important just before and during the Sa skya-Yuan perion (Phu ri was the centre of one of the administrative units called khri skor. The finding place is within the area of sMan khab, which together with the neighbouring Zur tsho were famous for their scribes and carvers. 


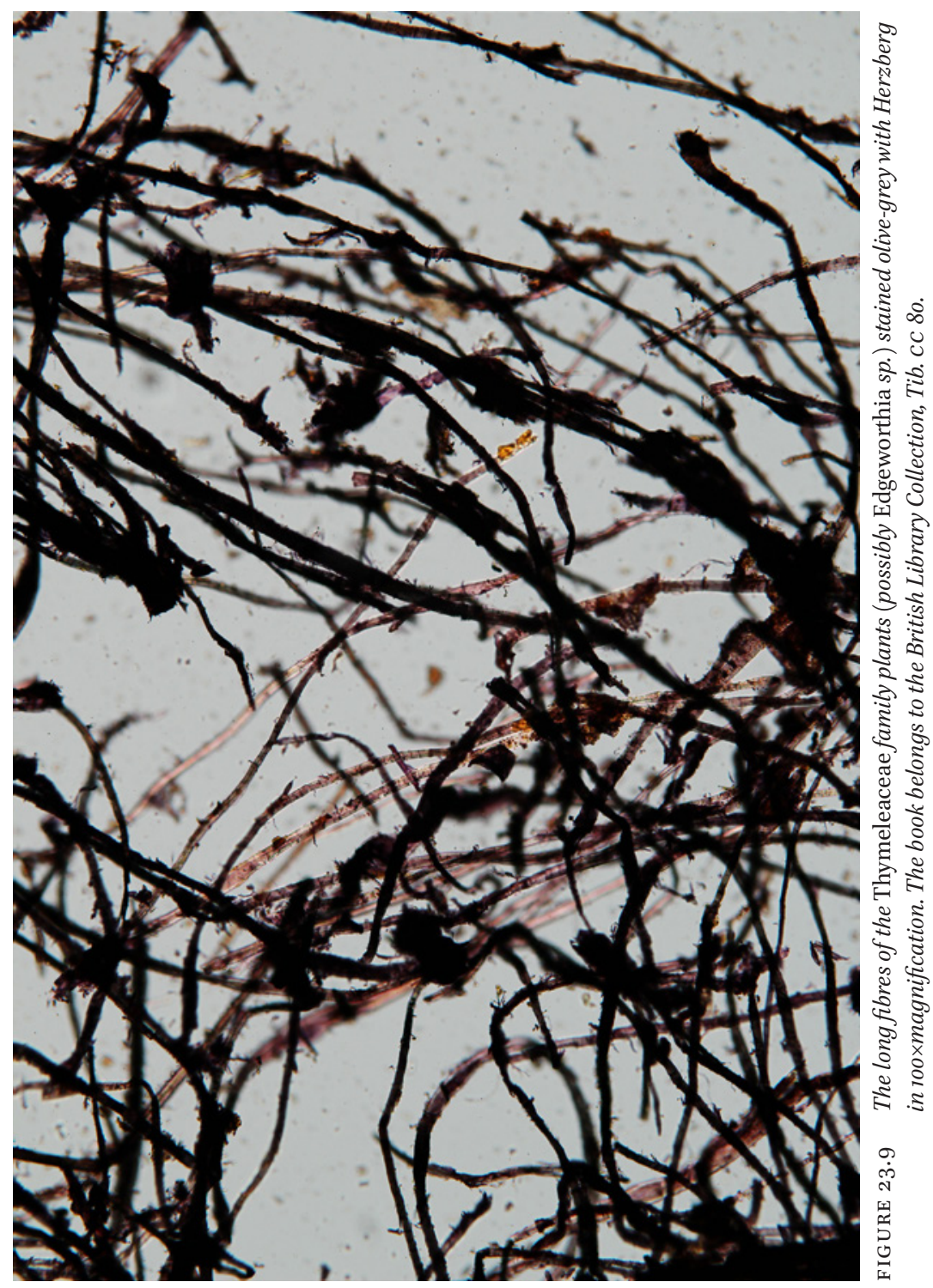




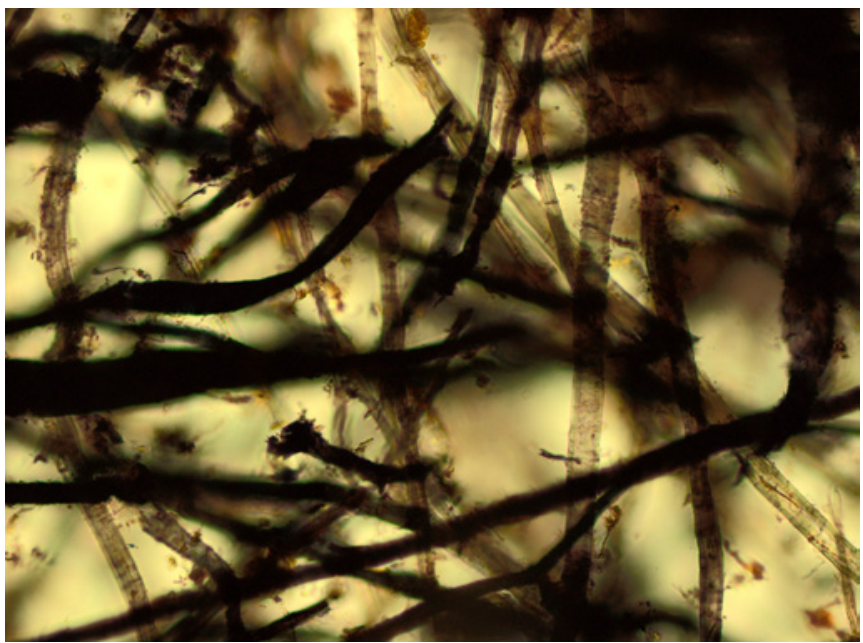

FIGURE 23.10 Stellera chamaejasme (re lcag pa) fibers with wide-irregular lumen and narrow cell-walls at $200 \times$ magnification observed in polarized light found in the Tibetan manuscript from the Tibet University Library, Phu ri Collection (TPooı).

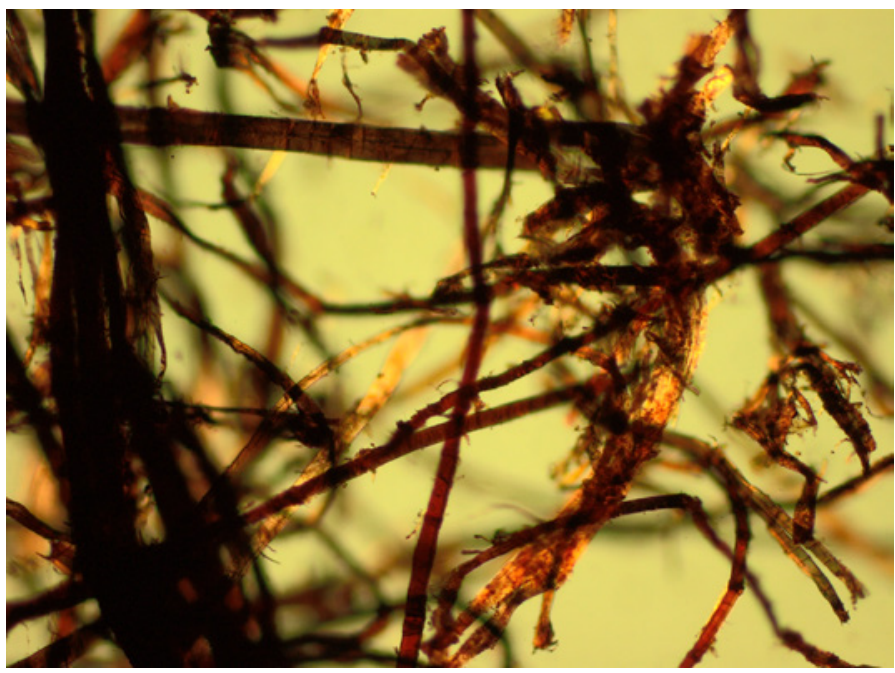

FIGURE 23.11 Hemp (Cannabis sativa) fibres stained reddish with Herzberg in 10oxmagnification found in the rag paper of the Tibetan manuscript from the Tibet University Library, Phu ri Collection (TP0151). 
one on Daphne/Edgeworthia sp. paper with addition of unidentified fibres; and one on paper made of Cannabis sp. (Hemp) (Fig. 23.10 and 23.11). I detected more early manuscripts from the same region on Stellera sp. paper.

The manuscript Mi la rnam mgur from the British Library (OR16756) was confirmed as written on pure Stellera paper. Also four of seven early manuscripts from the Pasang Wangdu collection from southern Central Tibet were made on paper dominated by Stellera fibres, and three others contained a significant addition of Stellera fibres. Only one manuscript from this group was made on rag paper based on ramie and hemp. Also from this group we have the earliest confirmed manuscript which contains the fibers of Stellera sp. plant mixed with Daphne/Edgeworthia sp. This is dated to the 1oth/11th century. This manuscript, discovered by Pasang Wangdu, originates from the area of bSam yas monastery in Central Tibet.

Furthermore the other early manuscript dated to the 11th c. written on mixed Daphne and Stellera paper is an illuminated manuscript (M81.90.6) from mTho lding in the collection of the Instituto per l'Africa e l'Oriente (IsIAO). Another paper of the same mixed composition is confirmed in a sample provided by Amy Heller from one of the Prajñāpāramitā manuscript volumes from the Bicher monastery in Dol po, Western Nepal.

\section{$3 \quad$ Concluding Remarks}

Most early xylograph prints were found in Central Asia along the Silk Road at the beginning of the 2oth century, and those are our primary sources for reconstructing the early history of printing. ${ }^{16}$ Later, two other regions became known as centres for the production of early Tibetan books, and these were Beijing and Central Tibet. Any attempt to reconstruct the history of printing and usage of paper is predicated on the materials available for investigation. At this point, information is scanty and fragmentary but what we known offers a starting point and a framework for future research. Our early history of Tibetan prints and paper is based on a relatively small collection of Tibetan books scattered over Asia. For this paper, I was able to examine for the first time a group of

16 These early manuscripts from the Silk Road, including examples of early prints, are located in more than twenty institutions around the world. Among others, the most significant collections of printed books can be found in the collections of the British Library in London, the Berlin-Brandenburgische Akademie der Wissenschaften, the Staatsbibliothek in Berlin, and the Institute of Oriental Manuscripts (гом) in St. Petersburg. 
both prints and manuscripts from a known and identified region. Additionally I supported my research on paper in old books with background knowledge of papermaking traditions still existing in these same areas. ${ }^{17}$

Books from Tibet proper especially certify the ability and skills of Tibetan craftsmen and the development of printing technology there. Other works printed along the Silk Road or in Beijing under the Mongol court were produced on local materials far beyond Tibet's borders and reveal significant differences. Chinese pagination in the early Tibetan prints from Khara Khoto and Beijing and other features suggest the involvement of local Chinese craftsmen in the production. Taking into consideration how distant these places are from each other (Beijing is ca. 220okm from Turfan) and considering environmental and cultural differences, it is not surprising that different types of paper were identified in the Tibetan printed books I studied, varying regarding to region. Furthermore, the types of raw materials used and technology applied significantly exceeds the typology assumed from the standard literature, which is that all papers in Tibetan books are made with Daphne sp. fibres on a woven type of mould.

The preliminary results of my investigation suggest that the choice of paper for printing was predicated on what was locally available and what could be imported through trade. Looking at such good quality paper used for the earliest prints I can say that printers probably selected the best available materials for their new technology. This explains the variety of paper components found in early prints in Tibetan, Chinese, and Uighur languages. Seemingly, the selection of paper at that time was not yet formalized; with time they adjusted the properties of available papers to whatever worked best with their printing methods.

The paper mulberry plant (Broussonetia sp.) was used for the finest papers in China since the beginning of papermaking and is usually associated with very fine paper supposedly produced at the Imperial Court in the first millennium and during the Ming Dynasty. There, paper of exceptional quality was used for art and calligraphy; however these papers were made with a fine bamboo sieve characterized by 24 or more laid lines in $3 \mathrm{~cm}$. All Kanjur sets produced in the Beijing area were executed on typically Chinese paper made of paper mulberry, or, later, a mixture of components such as paper mulberry, bamboo, and straw.

17 Information was gathered from interviews with craftsmen involved in papermaking and book production together with Hildegard Diemberger during fieldwork in Central and Western Tibet in June 2013. 
In contrast, all Kanjur sets produced in the Lhasa area and Central Tibet were printed on the Tibetan type of paper made of Daphne or Edgeworthia spp. of Thymelaeaceae family plants. I could observe the same split in paper features when examining fingerprinting patterns of papermaking sieves used (whenever it was possible). The majority of Tibetan papers was made with a woven sieve type (with no laid lines), and all Chinese papers were characterized by about 24-30 laid lines in 3 centimetres. In the examined Kanjur sets, papers were produced by means of moveable bamboo or grass sieve.

Altogether, I examined 50 samples from a clearly distinguished region of Central Tibet (La stod, Gung thang), and a few more from other areas. This helped to create my preliminary hypothesis. The paper chosen for printing in Central Tibet is relatively consistently based on Daphne/Edgeworthia fibres, whereas paper used in manuscripts has a greater range of variations. So far, I can tell that most early manuscripts were written on Stellera paper, or on paper where Stellera was a dominant component.

Stellera is closely related to Daphne; however, paper made with Daphne uses the bark from branches whereas paper made with Stellera chamaejasme uses the root bast. Although the quality of root paper is not as high as that made with bark, the presence of poison in the root paper makes it resistant to damage caused by insects and, ultimately, it is longer lasting than other types of paper. These root bast fibres create a very specific soft type of paper, which is considered to be of lower quality than bark paper because the fibres are not as strong. The roots are especially difficult to harvest, which places a serious limitation on the quantity of paper that can be produced. Root bast papers additionally require a longer time for processing, and an extra step in the papermaking process.

In principle, it should not be difficult to determine the relative importance of each of these different fibres in the early history of Tibetan papermaking. Stellera chamaejasme fibres are distinctive in the fibre examination of historic papers, and can be clearly differentiated from Daphne and Edgeworthia despite the fact that all plants belong to the Thymelaeaceae family.

The altitude range of Daphne sp. reaches $3600 \mathrm{~m}$ above sea level, and Stellera sp. is widely distributed along the Himalayan range at altitudes of 2700 to 4500 metres. And Daphne plants need much more moisture than Stellera. All this adds up to the fact that these two species very rarely grow in the same habitat. Because of this we can get a hint about the books' geographical origins based on which type of paper used.

For example, the fact that in my sample Stellera is confirmed mostly in early manuscripts on smaller formats suggests that Stellera was used for small local production. Taking into account the range and altitude of Stellera distribution 
it may be safe to assume that it was used on the plateau at higher altitudes. There was no real reason that paper made from Stellera, which is lower in quality and needs longer time to process, would be used in the valleys where Daphne is widely available. Thus, in my sample, as described above, Stellera is confirmed as the dominant component mostly in early manuscript from Phu ri Collection and Pasang Wangdu collection - both from Central Tibet - and also in early manuscripts from Western Tibet. These were produced on the plateau as hinted by the text.

Additionally from the technological point of view, since paper for manuscripts has to be processed before writing, it is possible to use a variety of fibres for its production regardless of their individual properties and strengths. The only limit influencing the selection was the size of the manuscript. Small formats of manuscripts were easily produced on pure Stellera paper, whose fibres are soft and flabby with a wide lumen and narrow irregular fibre walls. But Stellera alone is not stable enough for large formats (Stellera paper can easily bend or break). Even increasing the thickness of the Stellera paper by gluing it in layers was not enough to achieve the stability necessary for a large format, which is obvious in Daphne/Edgeworthia based papers.

The majority of early printed books from Tibet proper were on paper composed of Daphne/Edgeworthia sp. with addition of Stellera sp. made with woven type of sieve. Given what we have just discussed about the differences between the two plants' fibres and origins, this strongly suggests that this particular mix of raw materials was chosen intentionally for its particular properties. Daphne sp. has strong lignified fibres which give stability to paper, but alone is not a perfect material for printing. The addition of a small amount of Stellera sp. provides a softness and absorbent quality which probably explains why it is present in the books I examined. Further research will add to our story.

Summarizing, my preliminary results suggest that while early manuscripts produced locally were written on Stellera paper, the printing technology required usage of Daphne/Edgeworthia paper. Also Stellera was used extensively in early times, and probably later export of Daphne to the plateau increased, however, being probably conditioned by other economical and historical factors. This will be a subject of further study when I am able to collect more samples which cover the region more precisely.

\section{References}

Turfan Studies. 2007. Berlin-Brandenburg Academy of Sciences and Humanities. Berlin. Banik, Gerhard and Irene Brückle. 2011. Paper and Water: A Guide for Conservators. Amsterdam-Boston-Heidelberg-London: Elsevier and Butterworth-Heinemann. 
Carter, Thomas Francis. 1955. The Invention of Printing in China and its Spread Westward. New York: Ronald Press.

Dawa, Doctor. 1999. A Clear Mirror of Tibetan Medicinal Plants. Vol. 1. Rome: Tibet Domani Associazione.

Diemberger, Hildegard. 2012. "Quand le livre devient relique - Les textes tibétains entre culture bouddhique et transformations technologiques." Terrain, revue d'ethnologie europeénne 59: 18-39.

Diemberger, Hildegard and Michela Clemente. 2014. "Review of Bod kyi shing spar lag rtsal gyi byung rim mdor bsdus by Paltsek Research Institute". Inner Asia 16/1: 222-23.

Ehrhard, Franz-Karl. 200o. Early Buddhist Block Prints from Mang-yul Gung-thang. Vol. 1 (Lumbini International Research Institute Monograph Series 2) Lumbini: Lumbini International Research Institute.

Harrison, Paul. 1996. "A Brief History of the Tibetan Kanjur." In Tibetan Literature. Studies in Genre, edited by José Ignacio Cabezón and Roger R. Jackson, 70-94. Ithaca, New York: Snow Lion.

Helman-Ważny, Agnieszka. 2006. "Asian Paper in Works of Art: a Comparative Fiber Analysis." Hand Papermaking 21 no. 2, 3-9.

- 2009. "Recovering a Lost Literary Heritage: Preliminary Research on the Wanli Kanjur from Berlin." Journal of the International Association of Tibetan Studies, no. 5 . (http://www.thlib.org/collections/texts/jiats/\#!jiats=/05/helmanwazny/).

2014. The Archaeology of Tibetan Books. Leiden: Brill.

Helman-Ważny, Agnieszka and Sam van Schaik. 2013. "Witnesses for Tibetan Craftsmanship: Bringing Together Paper Analysis, Palaeography and Codicology in the Examination of the Earliest Tibetan Manuscripts." Archaeometry 55 (4): 707-741.

Koretsky, Elaine. 1986. "Papermaking Today in Tibet and China." Hand Papermaking 1 , 2-6.

van der Kuijp, Leonard W.J. 1993. "Two Mongol Xylographs (Hor Par Ma) of the Tibetan Text of Sa Skya Pandita's Work on Buddhist Logic and Epistemology." The Journal of the International Association of Buddhist Studies 16 (2), 279-298.

Mejor, Marek, Agnieszka Helman-Ważny, Thupten Kunga Chashab (ed.). 2010. A Preliminary Report on the Wanli Kanjur Kept at the Jagiellonian Library, Kraków. Research Centre of Buddhist Studies, Faculty of Oriental Studies, University of Warsaw, Warsaw (Studia Buddhica 1.).

Pan, Jixing. 1998. The History of Chinese science and technology: Paper making and Print. Beijing: Science Press.

Shaeffer, Kurtis R. 2009. The Culture of the Book in Tibet. New York: Columbia University Press.

Shi, Jinbo. 2005. "A study of the Earliest Tibetan Woodcut Copies." In China Tibetology Magazine (Chinese Edition) 4. Translated by Zhang Xiaomei available at the 
China Tibetology Information Center Website: zt.tibet.cn/english/zt/Tibetology Magazine/200312007420165155.htm (accessed on March 2013).

Snellgrove David, and Hugh Richardson. 1978. Tybet. Zarys Historii Kultury (A Cultural History of Tibet). Warszawa: Państwowy Instutut Wydawniczy.

Stoddard, Heather. 2010. "Stitched Books from the Tibetan World." Edition, éditions: l'écrit au Tibet, évolution et devenir edited by Anne Chayet et al., 363-379. Munich: Indus Verlag.

Trier, Jesper. 1972. Ancient Paper of Nepal. Result of ethno-technological field work on its manufacture, uses and history - with technical analyses of bast, paper and manuscripts. Copenhagen: Jutland Archaeological Society Publications.

Tsien, Tsuen-Hsuin. 1973. "Raw Materials for Old Papermaking in China." Journal of the American Oriental Society, vol. 93, no. 4, 510-519.

1985. Paper and Printing. Science and Civilisation in China, ed. Joseph Needham. Cambridge: Cambridge University Press.

Tsundru, Jampa. 2010. Preserve and Development of the Manufacturing Technology of Traditional Tibetan Paper. Lhasa: The Ethnic Publishing House. 